\title{
Effect of Zinc and Iron Fortification on Growth and Developmental Stages of Upland Irrigated Rice (Oryza sativa L.) Cultivars
}

\author{
S.R. Kadam*, V.M. Bhale, K.J. Kubade and M.R. Deshmukh \\ Dr. Panjabrao Deshmukh Krishi Vidhyapeeth, Akola (M.S), India \\ *Corresponding author
}

A B S T R A C T

Keywords

Zinc, Iron,

Fortification and rice cultivars

Article Info

Accepted:

14 December 2017

Available Online:

10 January 2018
Field studies were carried out during the growing season 2015-16 and 2016-17 at Research Farm, Department of Agronomy, Dr. Panjabrao Deshmukh Krishi Vidyapeeth, Akola (Maharashtra) to study "Effect of zinc and iron fortification on growth and developmental stages of upland irrigated rice (Oryza sativa L.) cultivars". The treatments were laid out in factorial randomized block design (FRBD) with three replications. Two years results shows that among varieties PBNR-03-02 explored highest growth and developmental stages whereas combine application of $\mathrm{ZnSO}_{4}+$ $\mathrm{FeSO}_{4}$ with RDF treatment recorded maximum growth and yield attributing characters respectively.

\section{Introduction}

Rice (Oryza sativa L.) being the staple food for almost two thirds of the population plays a pivotal role in Indian economy. Over 2 billion people in Asia alone derive $80 \%$ of their energy needs from rice, which contains $80 \%$ carbohydrates, $7-8 \%$ protein, $3 \%$ fat, and $3 \%$ fiber. India ranks first in the world in area of rice cultivation with 43.97 million ha and second in production with 104.32 million tons (Anonymous, 2013). In Maharashtra, the area under rice cultivation is 14.99 lakh ha, with annual rough rice production of 32.37 lakh tones, and productivity $2.01 \mathrm{t} \mathrm{ha}^{-1}$. Maharashtra ranks $13^{\text {th }}$ place in rice production in country and in case of Vidarbha region, area under upland rice is 7800 ha with production of 5600 tons and yield is about 718 $\mathrm{kg} \mathrm{ha}{ }^{-1}$.

$\mathrm{Zn}$ and $\mathrm{Fe}$ deficiencies are widespread health problems. Iron deficiency is the most common nutritional disorder not only in the world, and almost 1.6 billion people are suffering from iron deficiency (De Benoist et al., 2008). Iron deficiency anemia is by far the most widespread micronutrient deficiency, and it results in impaired physical growth, mental development, and learning capacity (Bouis, 2003). Similarly, Zinc deficiency is equally serious and is ranked as the $5^{\text {th }}$ leading 
risk factor for diseases in the developing world (Maret and Sandstead, 2006). Numerous health problems link zinc deficiency to retarded growth, skeletal abnormalities, delayed wound healing, increased abortion risk, and diarrhea (Salgueiro et al., 2000). Approximately onethird of the world's population is suffering from zinc deficiency (Hotz and Brown, 2004). The situation is even more adverse in developing countries where more than half of the children and pregnant women are suffering from iron and zinc deficiencies (Seshadri, 2001). This situation is largely attributed to the high consumption of cereal based foods viz., rice (Oryza sativa L.), wheat (Triticum aestivum L.), and maize (Zea mays L.), in these countries (Pfeiffer and McClafferty, 2007). Edible parts (endosperms) of modern cereal cultivars are inherently poor in iron and zinc. The concentration of iron in the brown rice ranges from 6.3 to $24.4 \mathrm{mg} \mathrm{kg}^{-1}$ and zinc concentration ranges from 15.3 to $58.4 \mathrm{mg}$ $\mathrm{kg}^{-1}$ (Gregorio et al., 2000). However, polished rice, the principal form of rice consumed, on an average contains only $2 \mathrm{mg}$ $\mathrm{kg}^{-1}$ iron and $12 \mathrm{mg} \mathrm{kg}^{-1}$ zinc (Barry, 2006).

The existence of a negative relationship between irrigation and iron and zinc uptake (Scagel et al., 2012) and a similar negative relationship between phosphorus and iron and zinc uptake (Saha et al., 2013) also lead to lower the accumulation of these micronutrients in the cereal grains. Since the edible parts of the cereals are poor in iron and zinc, thus heavy dependence of people from developing countries on these foods results in the development of large-scale iron and zinc malnutrition. To alleviate iron and zinc deficiency, it is required to increase iron and zinc concentration in the endosperm to 8 and $30 \mathrm{mg} \mathrm{kg}^{-1}$, respectively. Currently, there is growing concern to address micronutrient malnutrition through different interventions. Typically, these interventions are categorized into 4 major groups: pharmaceutical supplementation, industrial fortification, dietary diversification, and biofortification (Meenaski et al., 2007). In case of biofortification research efforts focused on development of high-yielding varieties and adoption of modern production technologies resulted in enhanced production leading to self-sufficiency in the country. Considering the all facts stated above, the present investigation entitled "Effect of zinc and iron fortification on growth and developmental stages of upland irrigated rice (Oryza sativa L.) cultivars" was planned with the objective to study the effect of Zinc and Iron on growth, yield and quality of upland rice cultivars.

\section{Materials and Methods}

Two field experiments were conducted at Research Farm, Department of Agronomy, Dr. Panjabrao Deshmukh Krishi Vidyapeeth, Akola (Maharashtra) during growing seasons 2015-16 and 2016-17. Texturally the soil was clay. It contained $8.6 \mathrm{pH}, 0.28 \mathrm{EC}, 0.52$ (g $\mathrm{kg}^{-1}$ ) organic carbon, $217.2 \mathrm{~kg} \mathrm{ha}^{-1}$ available $\mathrm{N}, 16.89 \mathrm{~kg} \mathrm{ha}^{-1}$ available $\mathrm{P}, 374.39 \mathrm{~kg} \mathrm{ha}^{-1}$ available $\mathrm{K}, 0.72 \mathrm{mg} \mathrm{kg}^{-1}$ available $\mathrm{Zn}, 9.01$ $\mathrm{mg} \mathrm{kg}^{-1}$ available Fe contents. The experiment was arranged in a factorial randomized block design with three replications, each plot being $3.6 \mathrm{~m} \mathrm{x} 4 \mathrm{~m}$. Sowing of upland irrigated rice was done on $31^{\text {st }}$ July 2015 during first year and on $26^{\text {th }}$ June 2017 during second year by drilling seeds per hill on $30 X 10 \mathrm{~cm}$.

Experiment consist of two factors namely varieties and nutrients. Varieties were consisted of three varieties viz., V1Sindewahi-1 (SYE-1), V2- Sindewahi-2001 (SYE-2001), V3- PBNR-03-02 and treatments were N1-RDF, N2- RDF + $\mathrm{ZnSO}_{4}(25 \mathrm{~kg}$ $\left.\mathrm{ha}^{-1}\right), \mathrm{N}_{3}-\mathrm{RDF}+\mathrm{FeSO}_{4}\left(30 \mathrm{~kg} \mathrm{ha}^{-1}\right), \mathrm{N}_{4}-\mathrm{RDF}+$ Foliar spray of $\mathrm{ZnSO}_{4} @ 0.5 \%$ at flowering and dough stage, $\mathrm{N}_{5}-\mathrm{RDF}+$ Foliar spray of $\mathrm{FeSO}_{4} @ 1.0 \%$ at flowering and dough stage, 
$\mathrm{N}_{6}-\mathrm{RDF}+\mathrm{ZnSO}_{4}+\mathrm{FeSO}_{4}\left(25+30 \mathrm{~kg} \mathrm{ha}^{-1}\right)$. Five plants were selected from each plot at random. Each plant marked with a small plastic white coloured ring and with wooden peg nearby for demarkation. The same five plants were observed at various stages of crop growth up to harvest for biometric observations. These five plants were harvested separately for post harvest observations.

\section{Results and Discussion}

The results obtained from the present investigation have been presented under following heads.

\section{Growth characters}

\section{Plant height (cm)}

\section{Effect of varieties}

Data pertaining to varieties revealed that maximum plant height $(35.28$ and $42.25 \mathrm{~cm})$ was recorded by variety PBNR-03-02 which was statistically superior over SYE-1 and SYE-2001 during both years of experimentation. However, lowest plant height (29.87 and $34.48 \mathrm{~cm}$ ) was observed in SYE2001. The maximum height of variety PBNR03-02 was mostly due to its genetic potential which was reflected in the plant height of all the varieties in second year mainly because of most favorable climate prevailed. Similar results were enclosed by Mannan et al., (2012)

\section{Effect of nutrients}

Data presented in the Table 1 showed that during first year and second year of investigation the combine application of zinc and iron along with RDF had a significant effect on the plant height during harvest stage. The comparison of treatment means revealed that soil application of zinc and iron together with $\mathrm{RDF}\left(\mathrm{N}_{6}\right)$ consistently maintained tallest plant height. Combination of soil application of $\mathrm{Zn}$ and $\mathrm{Fe}$ shows best results because applying nutrients viz. $\mathrm{Zn}$ and Fe to the soil is efficient because in soil solution they are present as positively charged metal ions and will readily react with oxygen or negatively charged hydroxide ions $\left(\mathrm{OH}^{-}\right)$. Iron has structural role in chlorophyll, energy transfer within the plant and enters in root cells also zinc increased plant height via increasing internodes distance. Similar result was obtained by Ananda and Patil (2005).

\section{Interaction effect}

The interaction effect of varieties and nutrients on plant height was found to be non significant during the course of investigation.

\section{No. of functional leaves}

Plants growing in good condition develop leaves in faster rate than those leaves growing in non conductive environment Data pertaining to the number of functional leaves per plant as affected by various treatments are presented in Table 1.

The difference in number of functional leaves plant $^{-1}$ due to genotypic character of varieties was found to be significant except during both the year. Variety PBNR-03-02 was found significantly superior over SYE-1 and SYE2001 during both the year of trial, however variety SYE-1 at harvest during 2015-16 and 2016-17 was at par with the PBNR-03-02. Variety SYE-2001 exhibited less number of functional leaves.

During the year 2016-17 maximum growth of leaves occurred as compared to previous year due to vegetative growth by favorable weather condition. The variations in number of leaves per plant attributed to the differences in the genetic makeup of the varieties and their differences in the utilization ability of the 
different rates of fertilizer applied. These observations are in consonance with that of Dixit and Patro (1994)

\section{Effect of nutrients}

During 15-16 combined application of $\mathrm{ZnSO}_{4}$ and $\mathrm{FeSO}_{4}$ along with $\mathrm{RDF}\left(\mathrm{N}_{6}\right)$ produced significantly maximum functional leaves which were on par with $\mathrm{ZnSO}_{4}$ with $\mathrm{RDF}$ and significantly superior to rest of treatments. Maximum functional leaves were observed at combined application of $\mathrm{Zn}$ and $\mathrm{Fe}$ with RDF $\left(\mathrm{N}_{6}\right)$ which was on par with $\mathrm{RDF}+\mathrm{FeSO}_{4}$ and found significantly superior at rest of the treatments. Supplemented $\mathrm{Zn}$ and $\mathrm{Fe}$ along with RDF, exhibited significantly more functional leaves during 16-17.

Combination of $\mathrm{ZnSO}_{4}$ and $\mathrm{FeSO}_{4}$ with RDF $\left(\mathrm{N}_{6}\right)$ enhanced the leaf production significantly during both the years. Micronutrients may be responsible for prolific leaf production combine with $\mathrm{RDF}$, as nitrogen, being the main constituent of chlorophyll, increased the photosynthetic efficiency of crop which resulted in higher leaf counts. Production of greater number of leaves in these treatments might be attributed to availability of $\mathrm{Zn}, \mathrm{Fe}$ and $\mathrm{RDF}$ Similar results were also observed by Dahiphale (2002) at VNMKV, Parbhani.

\section{Interaction effect}

Interaction effect between the varying varieties and nutrients over number of functional leaves was found to be nonsignificant in both years.

\section{No. of tillers $\mathbf{m}^{-2}$}

\section{Effect of varieties}

Data in Table 1 show that variety PBNR-03$02\left(V_{3}\right)$ has recorded highest number of tillers plant $^{-1}$ which was significantly more than rest of varieties, however variety SYE-1 $\left(\mathrm{V}_{1}\right)$ and SYE-2001 $\left(\mathrm{V}_{2}\right)$ were statistically at par with each other to produce tillers during 2016 and 2017. As the tillers of the plant are controlled by the genetic factors the differences in tiller were observed as reported. Bangladesh Rice Research Institute (2000).

\section{Effect of nutrients}

During both the years of trial a significant variation in number of tillers plant ${ }^{-1}$ was recorded due to various treatments as shown in Table 1. At harvest stage significantly highest production of tillers per plant was explored by the application of RDF with $\mathrm{ZnSO}_{4}\left(25 \mathrm{~kg} \mathrm{ha}^{-1}\right)+\mathrm{FeSO}_{4}\left(30 \mathrm{~kg} \mathrm{ha}^{-1}\right)\left(\mathrm{N}_{6}\right)$ than rest of the treatments, consecutively for two years, it may ascribed higher amount of macro and micronutrient availability and uptake. Alone application of nutrient $\mathrm{FeSO}_{4}$ $\left(30 \mathrm{~kg} \mathrm{ha}^{-1}\right.$ ) recorded marginally higher number of tiller which was at with the with $\mathrm{RDF}+\mathrm{ZnSO}_{4}\left(25 \mathrm{~kg} \mathrm{ha}^{-1}\right)$ over Recommended dose of fertilizer followed by Foliar application of $\mathrm{Fe} \quad \mathrm{SO}_{4} \quad\left(\mathrm{~N}_{5}\right)$ and Foliar application of $\mathrm{ZnSO}_{4}\left(\mathrm{~N}_{4}\right)$ was compare with each other the pattern was similar for both the years of experimentation.

\section{Interaction effect}

Interaction effect of different varieties and RDF with micronutrients was found nonsignificant.

\section{Total dry matter (gm)}

\section{Effect of varieties}

During first year of experimentation maximum dry matter accumulation $\left(\mathrm{g}\right.$ plant $\left.{ }^{-1}\right)$ was recorded by the variety PBNR-03-02 $\left(\mathrm{V}_{3}\right)$ which was significantly superior over rest of two varieties. 
Table.1 Growth characters of upland irrigated rice cultivars as influenced by different treatments during 2015-16 and 2016-17

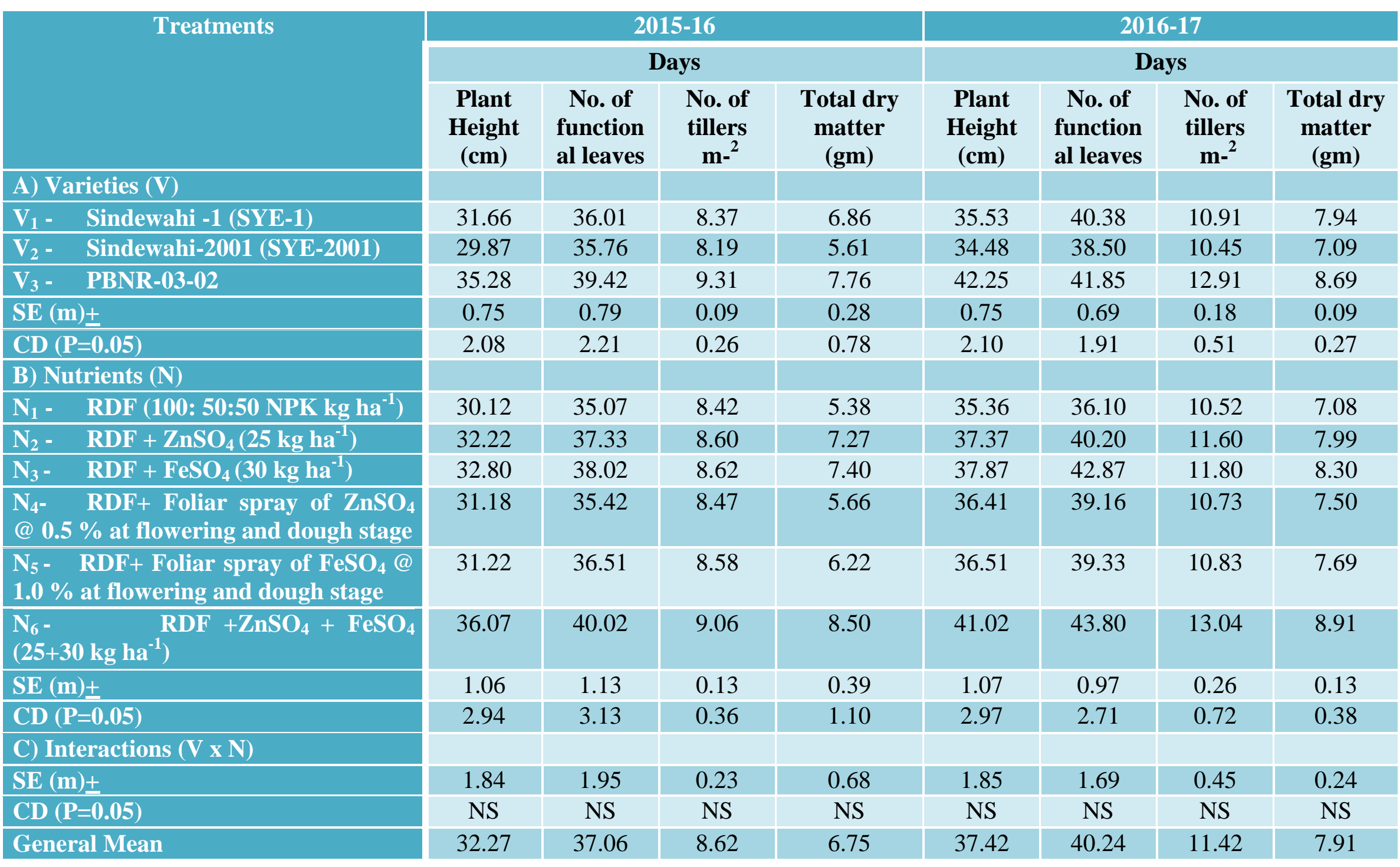


Table.2 Developmental stages of upland irrigated rice cultivars as influenced by different treatments during 2015-16 and 2016-17

\begin{tabular}{|c|c|c|c|c|c|c|c|c|}
\hline \multirow[t]{3}{*}{ Treatments } & \multicolumn{4}{|c|}{ 2015-16 } & \multicolumn{4}{|c|}{ 2016-17 } \\
\hline & \multicolumn{4}{|c|}{ Days } & \multicolumn{4}{|c|}{ Days } \\
\hline & $\begin{array}{c}\text { Panicle } \\
\text { initiation }\end{array}$ & $\begin{array}{c}50 \% \\
\text { heading }\end{array}$ & $\begin{array}{c}50 \% \\
\text { flowering }\end{array}$ & $\begin{array}{c}\text { Grain } \\
\text { maturation }\end{array}$ & $\begin{array}{l}\text { Panicle } \\
\text { initiation }\end{array}$ & $\begin{array}{c}50 \% \\
\text { heading }\end{array}$ & $\begin{array}{c}50 \% \\
\text { flowering }\end{array}$ & $\begin{array}{c}\text { Grain } \\
\text { maturation }\end{array}$ \\
\hline \multicolumn{9}{|l|}{ A) Varieties (V) } \\
\hline $\mathrm{V}_{1}-\quad$ Sindewahi -1 (SYE-1) & 33 & 60 & 74 & 91 & 36 & 62 & 81 & 94 \\
\hline $\mathrm{V}_{2}-\quad$ Sindewahi-2001 (SYE-2001) & 40 & 67 & 85 & 98 & 43 & 70 & 91 & 102 \\
\hline V ${ }_{3}-$ PBNR-03-02 & 32 & 52 & 68 & 87 & 36 & 55 & 72 & 91 \\
\hline $\mathrm{SE}(\mathrm{m}) \pm$ & 0.60 & 0.66 & 0.44 & 0.66 & 0.62 & 0.99 & 0.52 & 1.13 \\
\hline $\mathrm{CD}(\mathrm{P}=0.05)$ & 1.66 & 1.85 & 1.23 & 1.84 & 1.72 & 2.75 & 1.44 & 3.13 \\
\hline \multicolumn{9}{|l|}{ B) Nutrients (N) } \\
\hline $\mathrm{N}_{1}-\quad$ RDF (100: 50:50 NPK kg ha $)$ & 33 & 59 & 76 & 94 & 38 & 62 & 81 & 91 \\
\hline $\mathrm{N}_{2}-\quad \mathrm{RDF}+\mathrm{ZnSO}_{4}\left(25 \mathrm{~kg} \mathrm{ha}^{-1}\right)$ & 34 & 61 & 77 & 94 & 37 & 64 & 82 & 96 \\
\hline $\mathrm{N}_{3}-\quad \mathrm{RDF}+\mathrm{FeSO}_{4}\left(30 \mathrm{~kg} \mathrm{ha}^{-1}\right)$ & 35 & 60 & 77 & 93 & 38 & 62 & 81 & 96 \\
\hline $\begin{array}{l}\mathrm{N}_{4^{-}} \quad \mathrm{RDF}+\text { Foliar spray of } \mathrm{ZnSO}_{4} @ \\
0.5 \% \text { at flowering and dough stage }\end{array}$ & 36 & 57 & 76 & 90 & 39 & 60 & 83 & 97 \\
\hline $\begin{array}{l}\mathrm{N}_{5}-\mathrm{RDF}+\text { Foliar spray of } \mathrm{FeSO}_{4} @ \\
1.0 \% \text { at flowering and dough stage }\end{array}$ & 36 & 57 & 75 & 88 & 38 & 60 & 81 & 97 \\
\hline $\begin{array}{l}\mathrm{N}_{6}- \\
\left(25+30 \mathrm{~kg} \mathrm{ha}^{-1}\right)\end{array}$ & 37 & 63 & 72 & 93 & 39 & 66 & 80 & 97 \\
\hline $\mathrm{SE}(\mathrm{m}) \pm$ & 0.85 & 0.94 & 0.62 & 0.94 & 0.87 & 1.40 & 0.73 & 1.59 \\
\hline $\mathrm{CD}(\mathrm{P}=0.05)$ & 2.35 & 2.62 & 1.74 & 2.61 & N.S & N.S & N.S & N.S \\
\hline \multicolumn{9}{|l|}{ C) Interactions ( $\mathbf{V} \times \mathbf{N})$} \\
\hline SE (m) \pm & 1.47 & 1.63 & 1.08 & 163 & 1.52 & 2.43 & 1.27 & 2.76 \\
\hline $\mathrm{CD}(\mathrm{P}=0.05)$ & NS & NS & NS & NS & NS & NS & NS & NS \\
\hline General Mean & 35 & 59 & 75 & 92 & 38 & 62 & 81 & 96 \\
\hline
\end{tabular}


However variety SYE-1 was at par with the variety SYE-2001 $\left(\mathrm{V}_{2}\right)$. but in next year variety $\quad \mathrm{V}_{3}$-(PBNR-03-02) yielded significantly higher dry matter at all the stages. However Sindewahi-1 was significantly superior to Sindewahi-2001 at harvest. This observed because of the natural endowments of crop cultivars to optimally utilize available nutrients and subsequently partition its photosynthates for dry matter accumulation and/or conversion to economic yield vary (Ndon and Ndaeyo, 2001).

\section{Effect of nutrients}

Maximum dry matter production was observed with combination of $\mathrm{ZnSO}_{4}+\mathrm{FeSO}_{4}$ $\left(25+30 \mathrm{~kg} \mathrm{ha}^{-1}\right)$ with RDF which was significantly superior over rest of the nutrient management. The application of $\mathrm{FeSO}_{4}$ was found comparable with $\mathrm{ZnSO}_{4}$ along with $\mathrm{RDF}$ and found significantly superior over RDF alone. Foliar spray of $\mathrm{ZnSO}_{4}$ and $\mathrm{FeSO}_{4}$ were comparable to produce more or less equal dry matter production but found significantly superior over soil application of RDF during 2016.

During 2017 maximum dry matter was noticed with $\mathrm{ZnSO}_{4}$ and $\mathrm{FeSO}_{4}$ which was found significantly higher than rest of the treatments. Addition of $\mathrm{ZnSO}_{4}$ and $\mathrm{FeSO}_{4}$ produced significantly higher dry matter over the $\mathrm{RDF}$ alone foliar spray of $\mathrm{FeSO}_{4}$ and $\mathrm{ZnSO}_{4}$ were comparable but found significantly superior over RDF alone.

The apparent and significantly higher dry matter accumulation in wheat plant obtained with $\mathrm{RDF}$ with $\mathrm{ZnSO}_{4}+\mathrm{FeSO}_{4}$ compared to the values obtained in other treatments in this study, might be due to better nourishment derived from the soil as a result of balanced fertilization which improves soil nutrient status. Moreover, the initiation and development of tillers is very much dependent on the concentration of $\mathrm{N}, \mathrm{P}$ and $\mathrm{K}$ in the mother stem at tillering stage of crop. Another reason is when $\mathrm{Zn}$ and $\mathrm{Fe}$ provided in combination with $\mathrm{RDF}$ as soil application distribution of $\mathrm{Zn}$ and $\mathrm{Fe}$ within rice plant occurs through xylem and retranslocation in phloem which increases vegetative tissue formation resulted in improved photosynthetic activity which shows boosted growth of plant parts and increment in dry matter. These results are supported by Nadim et al., (2012)

\section{Interaction effect}

The different factors under study did not interact significantly in respect of dry matter accumulation at all growth stages of crop.

\section{Development stage of rice}

As the tillering stage comes to complete, they would develop flowers. These flowers are more commonly called as panicles. After the panicle initiation further phenotyping of rice crop starts.

\section{Effect of varieties}

The data depicted in the Table 2 revealed that the rice requires 52 and 70 days for $50 \%$ flowering and 78 and 91 days for grain maturation in 2015-16 and 2016-17 respectively.

In 2015-16, Variety PBNR-03-02 shows earlier Panicle initiation (32 ${ }^{\text {nd }}$ DAS), 50\% heading $\left(52^{\text {nd }} D A S\right), 50 \%$ flowering $\left(68^{\text {th }}\right.$ DAS) and grain maturation $\left(87^{\text {th }}\right.$ DAS $)$ as compared to 2016-17 and maturity was delayed in case of variety Sindewahi-2001.

During 2016-17, Panicle initiation of Sindewahi-1 and PBNR-03-02 was on same day, but PBNR-03-02 shows early 50\% heading, 50\% flowering and grain maturation 
over Sindewahi-1 and late phenological stages occurred in variety Sindewahi-2001.

This variation might be due to genetic makeup of cultivars. This Variations in crop growth period among different cultivars under different climatic condition is also reported by Khalifa et al., (2014)

\section{Effect of nutrients}

Alone application of RDF i.e. (100:50:50) recorded earlier panicle initiation $\left(33^{\text {rd }}\right.$ DAS) during 2015-16, 50\% heading occurred due to combination of Foliar spray of $\mathrm{FeSO}_{4} @ 1.0 \%$ and $\mathrm{ZnSO}_{4} @ 0.5 \%$ at flowering and dough stage with RDF $\left(57^{\text {th }}\right.$ DAS) and rice reached to its $50 \%$ flowering by the combine application of $\mathrm{N}_{6}-\mathrm{RDF}+\mathrm{ZnSO}_{4}+\mathrm{FeSO}_{4}$ $\left(25+30 \mathrm{~kg} \mathrm{ha}^{-1}\right) 72^{\text {th }}$ day in the same year. However in year 2016-17 panicle initiation, $50 \%$ initiation and grain maturation was earlier due to the foliar application of $\mathrm{FeSO}_{4}$ ( $1.0 \%$ on $88^{\text {th }}$ day.

During next year all the developmental stages of upland irrigated rice was not differ significantly due to various nutrient treatments.

In the present investigation, induction of early ear head emergence due to optimum supply of required essential plant nutrient, which have an influence on early ear head emergence in rice.

The results are in line with the findings of Sharma (2009) who had reported that days to flowering in wheat occurred significantly late in control plots, while it was earlier in $100 \%$ NPK applied to wheat.

\section{Interaction effect}

The Interaction effect between variety and nutrients was found non-significant at all developmental stages. On the basis of the results obtained, the following conclusions of significant and utility can be drawn

Variety PBNR-03-2 recorded significantly higher growth and developmental characters vary according to stages.

Soil application of RDF (100:50:50 kg ha $\left.{ }^{-1}\right)+$ $\mathrm{ZnSO}_{4}\left(25 \mathrm{~kg} \mathrm{ha}{ }^{-1}\right)+\mathrm{FeSO}_{4}\left(30 \mathrm{~kg} \mathrm{ha}^{-1}\right)$ recorded significantly highest growth and developmental studies.

\section{References}

Ananda N and Patil BN 2005. Influence of zinc, iron and time of nitrogen application on growth, yield and quality of durum wheat. Karnataka Journal of Agricultural Science, 18 (3):599-603

Barry G. 2006. High-iron and -zinc rice. Available from: http://www.knowledge bank.irri.org/rkb/health-and-nutrition/ high-ironand-zinc-rice.html, IRRI. Accessed 2014 January 20.

Bouis HE 2003. Micronutrient fortification of plants through plant breeding can it improve nutrition in man at low cost. Proc. Nutri. Soc. May: 62 (2): 403-11

BRRI (Bangladesh Rice Research Institute) 2000. Master Plan of Five Year Research Programme of the Bangladesh Rice Res. Inst. (2000-2005), Bangladesh Rice Res. Inst., Gazipur, pp.12-17

Dahiphale, AV 2002 Integrated nutrient management in basmati rice under upland condition. M. Sc (Agri) Thesis (unpub) submitted to Dr. PDKV, Akola

De Benoist $\mathrm{B}$, Mclean $\mathrm{E}$, Anderson $\mathrm{M}$, Rogers L 2008. Iodine deficiency in 2007: global progress since 2003. Food Nutr. Bull. 2008 Sep. 29 (3): 195-202

Dixit, U. C. and Patro, N 1994. Effect of NPK levels and plant density on yield attributes and yield of summer rice, 
Environment and Ecology, 12: 72-74. Gregorio GB 2002. Progress in breeding for trace minerals in staple crops. J. Nutr. 132:500S-502S.

Hotz C, Brown KH 2004. International Zinc Nutrition Consultative Group (IZiNCG). Assessment of the risk of zinc deficiency in populations and options for its control. Food Nutr Bull 25: S91-S204.

Khalifa, A., Ali, A., ELkhoby, W. and Okasha, E.M. 2014. Effect of sowing dates and seed rates on some rice cultivars. African Journal of Agricultural Research, 9(2): 196-201.

Mannan MA, Bhuiya MSU, Akhand MIM, Zaman MM 2012. Growth and yield of basmati and traditional aromatic rice as influenced by water stress and nitrogen level. Journal of Science foundation, 10: 52-62.

Maret W, Sandstead H 2006. Zinc requirements and the risk and benefits of zinc supplementation. J. Trace Element Med Biol., 20:3-18

Nadim MA, Awan IU, Baloch MS, Khan EA, Naveed K, Khan MA 2012. response of wheat (Triticum aestivum L.) to different micronutrients and their application methods. J. Anim. Plant Sci. 22(1): 113-119.

Ndon, B. A. and Ndaeyo, N. U. 2001. Evaluation of some cowpea (Vigna unquiculata (L.) Walp) cultivars adaptable to acid soils of Uyo, Southeastern Nigeria. Global Journal of
Pure and Applied Sciences, 7(3): 437441.

Pfeiffer WH, McClafferty B. Harvest Plus: breeding crops for better nutrition. Crop Science. 2007; 47: S88-S105.

Saha B, Saha S, Roy PD, Hazra GC and Das A 2013. Zinc fertilization effects on Agro-morphological and quality parameters of commonly grown rice. SAARC. J. Agri, 11(1): 105-120

Salgueiro MJ, Zubillaga M, lysionek A, Sarabia M, Caro R, Paoli TD, Hager A, Weill R, Boccaio J 2002. Zinc as an essential micronutrient: A Review, 20(5): 737-755

Scagel C, Bi G, Fuchigami L, Regan, R. 2012. Irrigation frequency alters nutrient uptake in container-grown Rhododendron plants grown with different rates of nitrogen. Hort. Sci. 47(2): 189-97.

Seshadri S 2001. Prevalence of micronutrient deficiency particularly of iron, zinc and folic acid in pregnant women in South East Asia. British Journal of Nutrition. 85, S87-S92.

Sharma, R. 2009. Effect of long term integrated nutrient management system on soil and crop productivity in ricewheat crop sequence. Thesis submitted to CSK Himachal Pradesh Krishi Vishwavidyalaya, Palampur (HP) in partial fulfillment of the requirements for the degree of Ph.D. (Agronomy).

\section{How to cite this article:}

Kadam, S.R., V.M. Bhale, K.J. Kubade and Deshmukh, M.R. 2018. Effect of Zinc and Iron Fortification on Growth and Developmental Stages of Upland Irrigated Rice (Oryza sativa L.) Cultivars. Int.J.Curr.Microbiol.App.Sci. 7(01): 1950-1958. doi: https://doi.org/10.20546/ijcmas.2018.701.236 